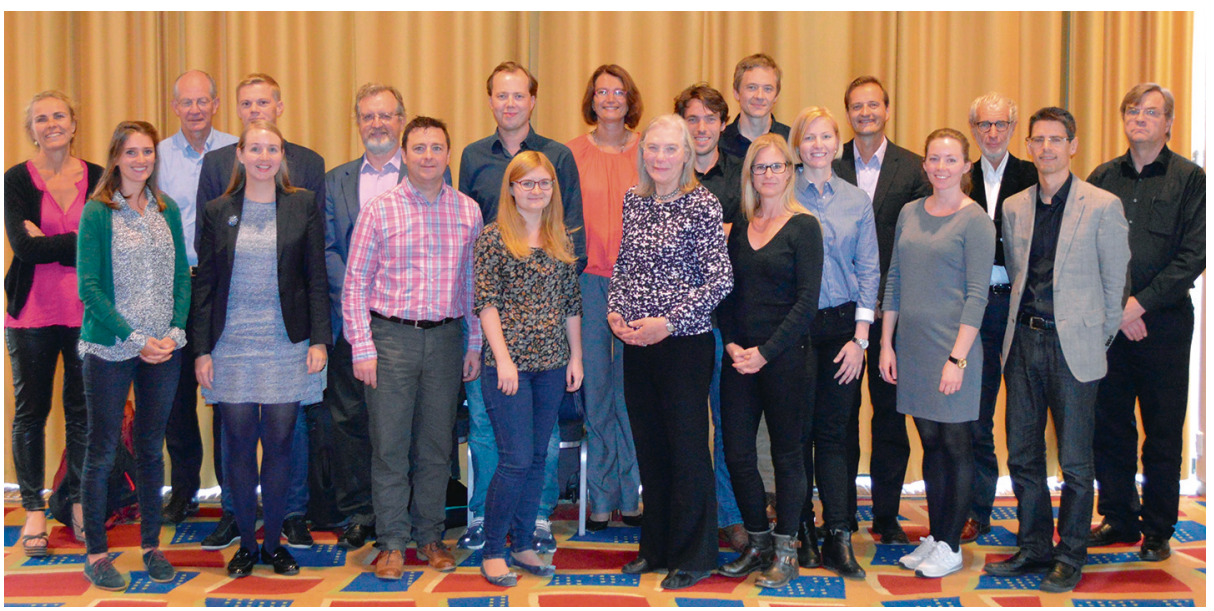

Studiegruppen NordICC. Foto: privat

\title{
Tarmkreftscreening med koloskopi
}

Tilbud om tarmskreftscreening med koloskopi gir godt oppmøte og funn av mange tarmpolypper, viser ny studie.

Koloskopiscreening er innført i flere europeiske land og i USA til tross for at det aldri er gjennomført en randomisert studie om effekten av koloskopiscreening på død og forekomst av kolorektal kreft, komplikasjoner, bivirkninger eller kostnadseffektivitet. En internasjonal studie ledet av norske forskere, nylig publisert i JAMA Internal Medicine, oppsummerer screeningperioden $\mathrm{i}$ perioden 2009-14 (1).

Studien omfatter flere enn 12500 personer i alderen 55-64 år som ble undersøkt med koloskopi i Norge, Sverige, Nederland og Polen. Oppmøteraten var høyest i Norge, der $61 \%$ av alle inviterte gjennomførte koloskopi. Lavest oppmøte var i Nederland (23\%). Kolorektal kreft ble påvist hos 62 personer $(0,5 \%)$, og adenomer ble fjernet hos flere enn 3800 personer (31\%). Patologiske funn var like hyppige i proksimale colon som i distale colon. Kun én pasient fikk tarmperforasjon og 18 fikk blødning etter polyppfjerning.

For coecumintubasjonsrate, adenomdeteksjon og pasientenes angivelse av smerter og ubehag var det signifikante forskjeller mellom legene som utførte koloskopiene. Om lag $17 \%$ av pasientene som ble undersøkt med luftinsufflering rapporterte middels eller sterke smerter etter koloskopien, mot kun $4 \%$ der det ble brukt kullsyregass.

- Denne studien viser at koloskopiscreening kan gjennomføres med høy deltagelse og liten risiko for komplikasjoner, sier professor Michael Bretthauer ved Oslo universitetssykehus, som er førsteforfatter for studien. - Variasjon i utførelsen av undersøkelsen mellom ulike leger tyder på at systematisk trening og utdanning av endoskopører bør prioriteres, sier han.
- Bruk av kullsyregass ga en signifikant reduksjon av smerter i forbindelse med koloskopi. I en annen artikkel som ble publisert 10.5. 2016, argumenterer vi i den norske gruppen for at kullsyregass bør bli standard ved alle koloskopier (2). Dette er innført ved mange norske sykehus, men i liten grad ved sykehus i utlandet, sier Bretthauer.

\section{Forskergruppe \\ for klinisk effektforskning}

Forfatterne bak studien kommer fra forskergruppen for klinisk effektforskning ved Institutt for helse og samfunn, Universitet i Oslo og Avdeling for transplantasjonsmedisin, Oslo universitetssykehus. Gruppen jobber med store kliniske studier, epidemiologi og metodeutvikling innenfor fordøyelsessykdommer, mammografi og kreftforebygging. Gruppen samarbeider tett med Sørlandet Sykehus, Sykehuset Telemark, Harvard School of Public Health og Karolinska Institutet. Gruppen leder nettverket Klinisk effektforskning i gastroenterologi i Helse Sør-Øst og er en del av K.G. Jebsen senter for tarmkreftforskning ved Oslo universitetssykehus og Universitet i Oslo.

\section{Kaveh Rashidi}

Tidsskriftet

\section{Litteratur}

1. Bretthauer M, Kaminski MF, Løberg M et al. Population-based colonoscopy screening for colorectal cancer: a European randomized trial. JAMA Intern Med 2016; e-publisert 23.5.2016.

2. Bretthauer M, Kalager M, Adami $\mathrm{HO}$ et al. Who is for $\mathrm{CO}_{2}$ ? Slow adoption of carbon dioxide insufflation in colonoscopy. Ann Intern Med 2016; e-publisert 10.5.2016.
Ordforklaringer

Koloskopiscreening: Screening for kolorektal kreft med bøyelig tarmkikkert etter å ha tømt tarmen med oral tømmingsvæske. Metoden brukes i USA og noen land i Europa, men er aldri blitt evaluert i en randomisert studie.

Adenom: En type polypp i tykk- eller endetarm som kan utvikle seg til kolorektal kreft. De fleste adenomer utvikler seg ikke til kreft, men de fleste tilfeller av kolorektal kreft oppstår fra adenomer. Adenomer kan fjernes med polyppektomi ved koloskopi. 